\title{
SOME FACTORS AFFECTING THE EXTENT OF ICE IN THE BARENTS SEA AREA
}

\author{
Francis E. Elliott*
}

\section{Introduction}

T $T$ is known that the areal distribution of ice in the arctic seas varies greatly from year to year, and considerable work has been done in an effort to find an explanation for this phenomenon in order to develop reliable methods of forecasting. Russian investigators are alleged to have made particularly good progress in this respect. As explained by Zubov (1948) the Russian method is based on the premise that "ice drifts along isobaric lines with a speed proportional to the pressure gradient". This method is used for forecasting from the winter and spring to the following navigation season. The weakness of this method lies in the fact that it assumes an unchanging amount of floating ice, drifting with the winds, concentrating in one part of the arctic seas and thinning out in other parts. It does not take into account the fact that 1ce melts when it comes into contact with warmer waters. Earlier, Zubov (1933) found a good correlation between the variation in temperature of the North Cape branch along the Kola meridian and the variation in the ice cover of the Barents Sea. This approach, however, neglected the variation in the inflow of warm Atlantic water into the area. An increased amount of warm Atlantic water obviously means an increased heat transport even if the temperature remains constant. Helland-Hansen (1934) found variations of about 20 per cent in transport across the Wyville-Thomson Ridge, and Jacobson's figures (1943) show an even greater range.

\section{Theoretical discussion of the method}

The present discussion is an attempt to explain the fluctuations in the areal extent of ice in the Barents Sea area (Fig. 1) through variations in the transport of the Florida current, as indicated by mean sea level changes at Charleston, South Carolina, and Miami Beach, Florida. This method seems entirely valid in the light of the investigations of Montgomery (1938), LaFond (1939), and Iselin (1940). They show that off a coast where the density of the water may vary owing to external influences, the variations in mean sea level have a direct bearing on the slope of the sea surface toward or away from the coast. Variations in mean sea level may thus be interpreted in terms of the slope of the sea surface, i.e., in terms of a coastal current. For the case at hand Iselin (1940) has demonstrated that increasing mean sea level at Miami Beach and

\footnotetext{
"Butler University, Indianapolis, Ind.
} 


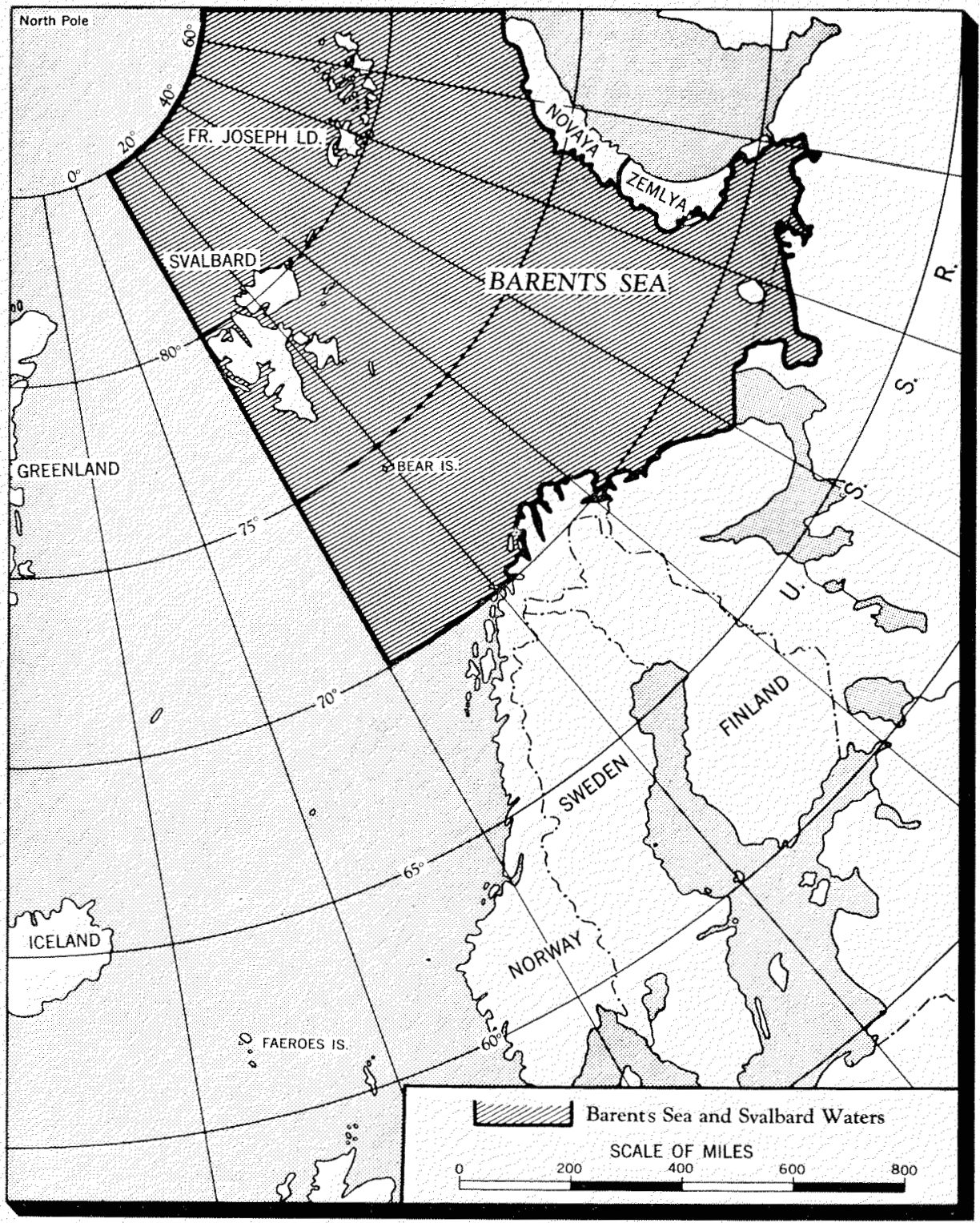

Fig. 1. Barents Sea area.

Charleston may be interpreted as decreased transport of the Florida current and decreasing mean sea level as increased transport. A better picture might have resulted if a tide gauge record had been obtained near the right edge of the current in conjunction with the one near the left edge. However, no such record exists since the gauge at Cat Cay was in operation for too short a period of time. 
The mechanism that links the changes in mean sea level at Miami Beach and Charleston with the flow of water of the Gulf Stream system into the Barents Sea is quite simple. Decreased sea level means increased transport in the system, contraction of the North Atlantic eddy, and decreased discharge of warm water across the Wyville-Thomson Ridge. Increased sea level will produce the opposite effects (Iselin, 1938; 1940). To substantiate the case further, Sverdrup (1938) states that increasing sea level is always accompanied by increasing temperatures, and conversely, decreasing sea level by decreasing temperatures; therefore, this approach not only accounts for the variation in water transport, but also in temperature. Our detailed knowledge of the Gulf Stream system is limited, and recent surveys have demonstrated that it is far from being a simple river in the ocean. For the purpose of this study this is unimportant, the current meanders or even turns back on itself occasionally, it widens and narrows, and it also shifts its course. The only important fact is that the Florida current is part of the Gulf Stream system and that part of its waters will reach the area under investigation. Mosby (1938) has investigated this aspect of the problem and arrived at the result that "extreme Spitsbergen-Atlantic water, north of Spitsbergen, should contain nearly 20 per cent of original Gulf Stream water from the Florida current."

Besides sensitivity of the mean sea level to the dynamics of the current, other significant influences to be considered are the direction of the prevailing winds, water temperatures, and atmospheric pressure (Montgomery, 1938). A study by this writer has shown that the influence of the prevailing winds on the mean sea level at the tide stations is only of the order of 0.004 foot for the total variation in the annual mean of wind velocity as determined by the U.S. Weather Bureau; this amount is small enough to be neglected. The correction for atmospheric pressure was based on the premises of Dietrich (1937), but as it would have been technically impossible to plot thousandths of an inch, the method was simplified by correcting with a factor of 12 to 1 instead of 13.2 to 1 . In other words, for 0.01 inch deviation of atmospheric pressure from the mean, an adjustment of 0.01 foot in sea level was made. In correcting for water temperatures an amount of 0.035 foot was used for each degree Fahrenheit deviation from the mean (Montgomery, 1938). Direction and intensity of the winds over the Barents Sea area have been considered in detail in this study. The Atlantic low pressure trough, also called the arctic front, extends over the Barents Sea area each year during the period of investigation and divides two different air masses. North of the front there is cold, continental polar air with northerly winds, south of the front there is warm, maritime polar air with southerly winds (Haurwitz and Austin, 1944). The longitudinal position of the arctic front changes from year to year, and since northerly winds drive ice from the polar basin into the area, this position seems to be important. The farther south the position of the arctic front, the larger will be the part of the Barents Sea area under the influence of cold air masses with northerly winds, and the larger should be the area covered by ice. Tabulated mean annual pressure data by intersections were plotted and mean annual 
pressure charts of the northern hemisphere were constructed. The position of the arctic front was determined and that part of the area covered by continental polar air was measured. The pressure gradient over the same area was determined in order to obtain an indication of the intensity of the wind. To make it possible to combine these two criteria and plot them as a graph, an index number was calculated by multiplying the area, expressed as percentage of the total, by the pressure gradient, and dividing the result by 100 . By this process an index figure was obtained that stands in the following relationship to the distribution of ice in the area under investigation: the larger the index figure, which is another way of saying the larger the area covered by cold air and northerly winds and the stronger these winds, the larger is the area covered by ice.

That the water temperature is more critical than air temperature has been demonstrated experimentally by Sandström (1918). A carefully measured block of ice was placed in flowing water at a temperature of $8^{\circ} \mathrm{C}$. The experiment was conducted in a room, and although it is not stated, it is safe to assume that the air temperature was about $20^{\circ} \mathrm{C}$. During the same length of time, about ten times as much ice was melted from the submerged part of the block as from the exposed part.

The time lag between the observed fluctuations of mean sea level at Miami and Charleston, the correlated changes in energy transport by the Florida current, and the effects of these changes in the Barents Sea area present a very important, but difficult problem. Since no direct evidence is available at present, the discussion must be concerned for the most part with indirect and supporting evidence. Zubov (1933) has made an estimate of this time lag. He concluded, on the basis of a statement by Sandström (1931), who said that the temperature of the Florida current in the summer of 1928 was $5^{\circ}$ above normal, that the very favourable ice conditions encountered in the northern Barents Sea by the Knipovitch and Persei expeditions in the summer of 1931 and the conditions north of Svalbard found by the Quest expedition in the same summer were caused by a "hot wave" emanating from the Gulf of Mexico and the Atlantic Ocean in the earlier year. Zubov even thinks that he circumnavigated Franz Josef Land in the summer of 1932 "on the crest of this "hot wave"".

The preceding estimate of the time lag is based upon one year's temperatures. A thorough search through available sources has revealed, however, that not enough temperature data are available to follow a "hot wave" or "cold wave" through the current system.

A new approach to arrive at a fairly reliable time lag was attempted through the use of current velocities. The best basis for the calculation of mean velocities would have been a great number of velocity cross-sections computed for many years at numerous points along the Gulf Stream system. Such a record is not available. As the next best source monthly current charts of the North Atlantic Ocean (U.S. Navy Hydrographic Office, 1946) were used. 
A hypothetical water particle was followed on its fastest route from the entrance of the Straits of Florida $\left(25^{\circ} \mathrm{N}, 80^{\circ} \mathrm{W}\right)$ to the vicinity of the Wyville-Thomson Ridge (about $60^{\circ} \mathrm{N}, 17^{\circ} \mathrm{W}$ ). In this computation a month was figured as closely as possible to 30 days, without dividing a $1^{\circ}$ square. The procedure is as follows: a water particle passing through $25^{\circ} \mathrm{N}, 80^{\circ} \mathrm{W}$ on the first of August was followed for about 30 days on the August chart, then, figuratively speaking, transferred to the September chart, and so on, until it reached $60^{\circ} \mathrm{N}, 17^{\circ} \mathrm{W}$. The results of this computation, with starting dates of August 1 and February 1, are shown in Table 1.

Table 1. Mean surface velocities in the axis of the Gulf Stream system from the entrance of the straits of Florida to the vicinity of the Wyville-Thomson Ridge

\begin{tabular}{|c|c|c|c|c|}
\hline Month & Co-ordinates & Distance in & Number of days & $\begin{array}{c}\text { Aver. dist } \\
\text { per day }\end{array}$ \\
\hline August & $38 \mathrm{~N} 64 \mathrm{~W}$ & 1250 & 32.1 & 38.9 \\
\hline September & $40 \mathrm{~N} 54 \mathrm{~W}$ & 460 & 28.4 & 15.9 \\
\hline October & $42 \mathrm{~N} 47 \mathrm{~W}$ & 325 & 30.1 & 10.8 \\
\hline November & $44 \mathrm{~N} 39 \mathrm{~W}$ & 370 & 32.2 & 11.5 \\
\hline December & $45 \mathrm{~N} 35 \mathrm{~W}$ & 170 & 29.3 & 5.8 \\
\hline January & $47 \mathrm{~N} 30 \mathrm{~W}$ & 220 & 31.9 & 6.9 \\
\hline February & $48 \mathrm{~N} 26 \mathrm{~W}$ & 170 & 32.1 & 5.3 \\
\hline March & $50 \mathrm{~N} 23 \mathrm{~W}$ & 130 & 30.2 & 4.3 \\
\hline April & $53 \mathrm{~N} 20 \mathrm{~W}$ & 190 & 28.0 & 6.8 \\
\hline May & $56 \mathrm{~N} 18 \mathrm{~W}$ & 130 & 28.3 & 4.6 \\
\hline June & $58 \mathrm{~N} 18 \mathrm{~W}$ & 120 & 29.3 & 4.1 \\
\hline \multirow[t]{2}{*}{ July } & $60 \mathrm{~N} 18 \mathrm{~W}$ & 120 & 15.2 & 7.9 \\
\hline & & & 347.1 & \\
\hline & $38 \mathrm{~N} 66 \mathrm{~W}$ & 1150 & 30.9 & 37.2 \\
\hline March & $39 \mathrm{~N} 55 \mathrm{~W}$ & 500 & 31.0 & 16.1 \\
\hline April & $42 \mathrm{~N} 47 \mathrm{~W}$ & 410 & 32.8 & 12.5 \\
\hline May & $46 \mathrm{~N} 42 \mathrm{~W}$ & 340 & 33.0 & 10.3 \\
\hline June & $49 \mathrm{~N} 37 \mathrm{~W}$ & 250 & 26.6 & 9.4 \\
\hline July & $49 \mathrm{~N} 32 \mathrm{~W}$ & 195 & 28.7 & 6.8 \\
\hline August & $49 \mathrm{~N} 29 \mathrm{~W}$ & 115 & 30.3 & 3.8 \\
\hline September & $50 \mathrm{~N} 25 \mathrm{~W}$ & 165 & 31.1 & 5.3 \\
\hline October & $53 \mathrm{~N} 21 \mathrm{~W}$ & 220 & 30.1 & 7.0 \\
\hline November & $57 \mathrm{~N} 18 \mathrm{~W}$ & 240 & 28.9 & 8.3 \\
\hline \multirow[t]{2}{*}{ December } & $60 \mathrm{~N} 16 \mathrm{~W}$ & 180 & 23.2 & 7.6 \\
\hline & & & 326.6 & \\
\hline
\end{tabular}

February and August were chosen as starting months because in these months the oceanic winter and summer reach their peak. The number of days spent in travel average 336 , or approximately 11 months. Since the velocity of a current is usually highest near the surface, this figure can be accepted as the minimum time lag between the Straits of Florida and the Wyville-Thomson Ridge.

As to the time lag from the Wyville-Thomson Ridge to Svalbard and the Barents Sea, there are indications (Helland-Hansen, 1934; Mosby, 1938) that the velocities of the Norwegian current and the Spitsbergen-Atlantic current are fairly uniform throughout their courses. They seem to diminish appreciably only after the latter current has rounded the northwest corner of West Spitsbergen. The overall distance from the Wyville-Thomson Ridge to this 
point is about 1460 nautical miles. The average velocity throughout the entire body of this current has been computed by the writer to be 3.67 nautical miles per day (Helland-Hansen, 1934). Under the assumption of a fairly uniform velocity of the current, this would mean that it takes the energy about 400 days or about 14 months to travel from the Wyville-Thomson Ridge to the northwest corner of West Spitsbergen.

The distance involved via the North Cape current into the Barents Sea is about the same as the one described above, and although no velocity calculations could be made because of the lack of velocity sections, it is safe to suppose that the time lag is similar.

Then, adding to the minimum approximate figure of 14 months the minimum time lag of one year from the straits of Florida to the WyvilleThomson Ridge, it appears that the variations in the flow of the Florida current will make themselves felt in the third year thereafter in the Barents Sea area.

\section{Method of presentation}

In order to show in a simple manner the influence of the Gulf Stream system on ice conditions in the Barents Sea (Fig. 1) the basic data in Table 2 were plotted as graphs (Fig. 2) from three base lines according to a rule derived from Iselin's theory of the expansion and contraction of the North Atlantic eddy $(1938 ; 1940)$. It would have been more desirable to use a continuous record from the tide gauge at Miami Beach since it is considerably closer to the edge of the Florida current and therefore more sensitive than the

Table 2. Basic data. Annual means of sea level at Charleston, S.C., and Miami, Fla., corrected for atmospheric pressure ${ }^{1}$ and surface water temperature ${ }^{2}$. Ice data. Index of northerly winds.

\begin{tabular}{|c|c|c|c|}
\hline Year & $\begin{array}{l}\text { Annual means of } \\
\text { sea level in feet } \\
\text { above zero of staff }\end{array}$ & $\begin{array}{c}\text { Ice data in } \\
\text { per cent of } \\
2,170,000 \mathrm{~km} .^{2}\end{array}$ & $\begin{array}{l}\text { Index of } \\
\text { northerly } \\
\text { winds }\end{array}$ \\
\hline 1922 & Charleston $^{3} 4.99$ & - & - \\
\hline 1923 & " $\quad 4.93$ & - & - \\
\hline 1924 & 5.00 & - & - \\
\hline 1925 & 5.03 & 46 & 1.4 \\
\hline 1926 & 4.82 & 53 & 0.7 \\
\hline 1927 & 4.87 & 55 & 2.0 \\
\hline 1928 & 4.96 & 51 & 1.2 \\
\hline 1929 & 4.94 & 56 & 1.4 \\
\hline 1930 & 4.95 & 46 & 1.0 \\
\hline 1931 & 4.82 & 45 & 0.8 \\
\hline 1932 & Miami ${ }^{4}$ & 50 & 1.5 \\
\hline 1933 & 3.40 & 43 & 1.1 \\
\hline 1934 & 3.30 & 51 & 0.9 \\
\hline 1935 & 3.40 & 51 & 1.3 \\
\hline 1936 & - & 46 & 1.0 \\
\hline 1937 & -- & 43 & 0.5 \\
\hline 1938 & - & 43 & 1.0 \\
\hline
\end{tabular}

1 Correction for atmospheric pressure: 0.01 inch $=0.01$ foot

${ }^{2}$ Cotrection for surface temperature: $1^{\circ} \mathrm{F}=0.035$ foot.

3 Mean atmos. press. 30.06 inches, mean sea surf. temp. $68^{\circ} \mathrm{F}$.

4 Mean atmos. press. 30.04 inches, mean sea surf. temp. $78.8^{\circ} \mathrm{F}$. 


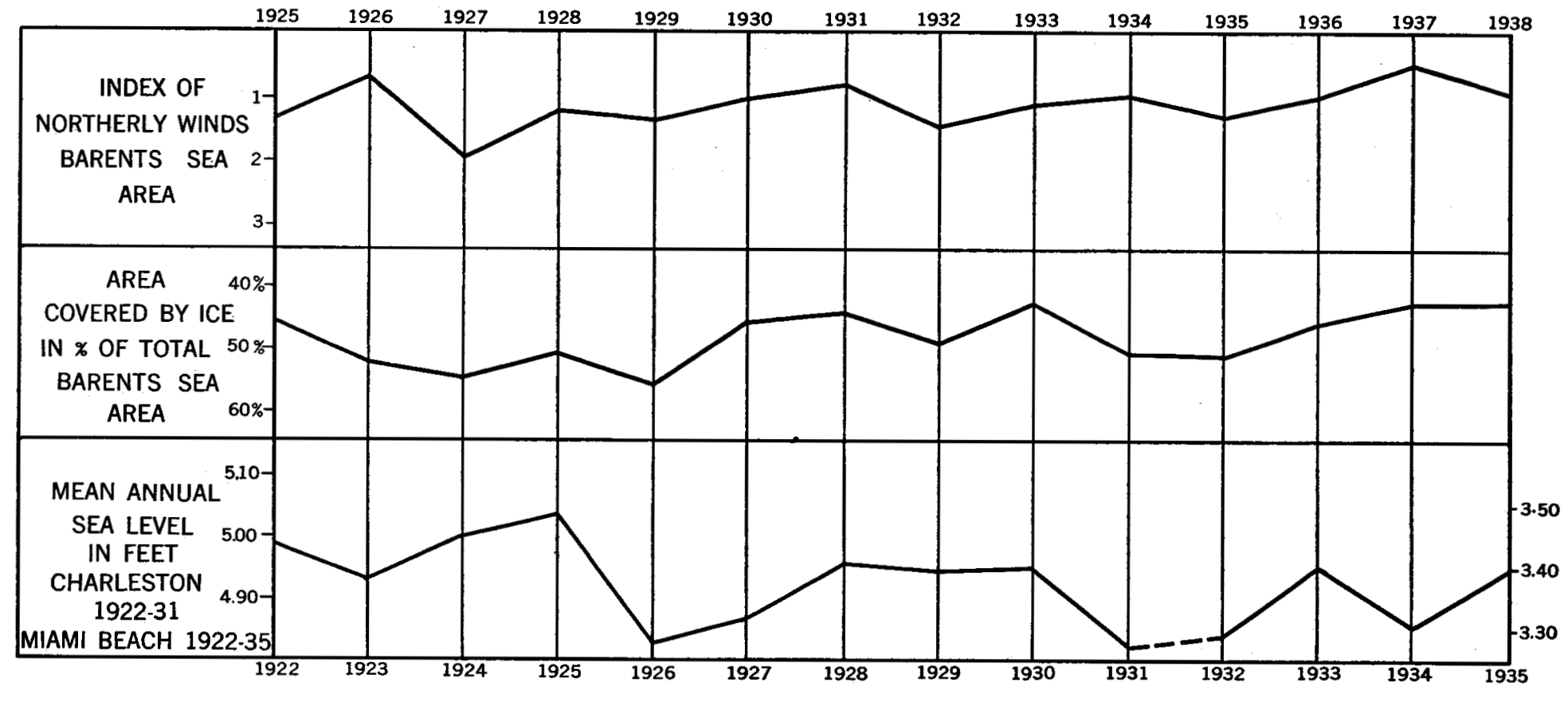

Fig. 2. Graphical representation of the basic data of Table 2. 
one at Charleston. Unfortunately, the gauge at Miami Beach was not installed until 1931, and the first full year of record available is 1932. To provide an adequate record, the sea level data at Charleston were used for the years 1922 to 1931 , and those at Miami for 1932 to 1935 . The sea level curves were plotted in such a way as to bring their overall mean for their periods of record on the same line. The mean for Charleston is 5.09 feet and that for Miami Beach 3.52 feet. The time lag of three years was taken care of by plotting the corresponding years on the same vertical line. Sea level data were plotted from the lower base line increasing upward. The ice data and the wind index were plotted from the upper base line, increasing downward. All curves were plotted to the same scale.

Following these guides the method becomes quite clear. Low sea level at Charleston and Miami Beach means strong flow, contraction of the North Atlantic eddy, little warm Atlantic surface water discharged into the Barents Sea area, and therefore more ice; high sea level at Charleston and Miami Beach means weak flow, expansion of the North Atlantic eddy, more warm Atlantic surface water discharged into the Barents Sea area, and therefore less ice. A similar rule applies to the wind index. A large area covered by continental polar air and strong northerly winds should mean more ice; a small area and weak winds should mean less ice.

\section{The relationship}

It is not possible at present to make a quantitative analysis of the relationship between changes in sea level and ice coverage. Neither the data nor our knowledge of the transport of energy in ocean currents are adequate for such a purpose. However, they are sufficient to permit a qualitative interpretation. In other words, this means that it is impossible to say that a change in sea level of 0.05 foot changes the ice cover by, say, 5 per cent. But it can be said that an increase in sea level for the reasons that have been explained should cause a retreat of the ice, and that a decrease in sea level should have the opposite effect.

Examining Fig. 2 and keeping the above statement in mind, one can say that the trend of the curves is generally the same. Taking the sea level curve and the ice curve under closer scrutiny, it is seen that they move up and down together in all cases, except two, that is, the pairs 1924/1927 and 1934/1937. With regard to the ice curve and the wind curve the deviations occur in 1926 and 1934. These discrepancies between the three curves do not occur at the same time. In each case there is good agreement between the plotted phenomena in 12 of the 14 cases. This does not permit a definite answer to the question whether the current or the distribution of the atmospheric pressure has a stronger influence on the extent of the ice. However, it is the writer's opinion that it establishes the fact that the inflow of warm Atlantic water through the Gulf Stream system apparently has a strong influence on the areal extent of ice in the Barents Sea area. 
All efforts to explain the discrepancies in the relationship between the discussed curves have been unsuccessful. Available data published by the Association d'Oceanographie Physique (1940), for instance, show that mean sea level in 1934 was low throughout the Atlantic Ocean and there is sufficient proof that 1937 was a light ice year (Danske Meteorologiske Institut, 1937). There must have been a disturbing factor in the relationship that cannot be explained at our present state of knowledge. It is the writer's opinion that the pressure distribution does not furnish the answer, because in 1926, to take an example, the pressure distribution should have resulted in a light ice year, whereas it actually was a fairly heavy one.

\section{References}

Association d'Oceanographie Physique. 1940. 'Monthly and annual mean heights of sea level'. Publication Scientifique No. 5.

Danske Meteorologiske Institut. 1937. 'Isforholdene $\mathrm{i}$ de arktiske have. (The state of the ice in the Arctic seas), 1892-1939'. Copenhagen.

Dietrich, G. 1937. I. "Die Lage der Meeresoberfläche im Druckfeld von Ozean und Atmosphäre"; II. "Ueber Bewegung und Herkunft des Golfstromwassers". Veröffentlichungen des Instituts für Meereskunde an der Universität Berlin, Neue Folge, A. Heft 33, pp. 1-91.

Haurwitz, B., and J. M. Austin. 1944. Climatology. New York.

Helland-Hansen, B. 1934. 'The Sognefjord section. Oceanographic observations in the northernmost part of the North Sea and the southern part of the Norwegian Sea'. James Jobnstone Memorial Volume. Liverpool: pp. 257-75.

Iselin, C. O'D. 1938. 'A promising theory concerning the causes and results of longperiod variations in the strength of the Gulf Stream system.' Trans. Am. Geophys. Union, 19th Annual Meeting, pp. 243-44.

1940. "Preliminary report on long-period variation in the transport of the Gulf Stream system". Papers in Physical Oceanography and Meteorology, Vol. 8, pp. 1-40.

Jacobson, J. R. 1943. "The Atlantic current through the Faeroes-Shetland channel and its influence on hydrographical conditions in the northern part of the North Sea, the Norwegian Sea, and the Barents Sea'. Rapp. et Proc.-verb. des Reunions, Cons. Perm. Int. p. l'Explor. de la mer, Vol. 112, pp. 5-47.

LaFond, E. C. 1939. "Variations of sea level on the Pacific coast of the United States". J. Mar. Res., Vol. 2, pp. 17-29.

Montgomery, R. B. 1938. "Fluctuations in monthly sea level on eastern U.S. coast as related to dynamics of western North Atlantic". J. Mar. Res., Vol. 1, pp. 165-85.

Mosby, H. 1938. "Svalbard waters". Geofysiske Publikasjoner, Vol, 12, No. 4.

Sandström, J. W. 1918. 'The hydronamics of Canadian Atlantic waters'. Canadian Fisheries Expedition 1914-15. Ottawa.

1931. "Der Golfstrom und das Wetter". Gerlands Beiträge zur Geophysik, Vol. 32, pp. 254-59.

Sverdrup, H. U. 1938. "Research within physical oceanography and submarine geology at the Scripps Institution of Oceanography during April, 1937, to April, 1938". Trans. Am. Geophys. Union, Vol. 19, pp. 238-42.

U.S. Navy, Hydrographic Office. 1946. 'Current atlas of the North Atlantic Ocean'. H. O. Misc. 10,688-1 to 12. Washington.

Zubov, N. N. 1933. "The circumnavigation of Franz Josef Land". Geogr. Rev., Vol. 23, p. 394ff. Inf. Service, Ottawa: 1950.

1948. 'In the centre of the Arctic', (transl. by E. Hope). Defence Sci. 